\title{
Radioactive Contaminants in U.S. Drinking Water and Water Quality Disparities
}

\author{
Kaleh Karim ${ }^{1,2}$, Sujata Guha1, Ryan Beni ${ }^{*}$ \\ ${ }^{1}$ Department of Chemistry, Tennessee State University, Nashville, TN, USA \\ ${ }^{2}$ Department of Biological Sciences, Tennessee State University, Nashville, TN, USA \\ Email: *rbeni@tnstate.edu
}

How to cite this paper: Karim, K., Guha, S., \& Beni, R. (2020). Radioactive Contaminants in U.S. Drinking Water and Water Quality Disparities. Journal of Geoscience and Environment Protection, 8, 238-251. https://doi.org/10.4236/gep.2020.811016

Received: September 18, 2020

Accepted: November 24, 2020

Published: November 27, 2020

Copyright (๑) 2020 by author(s) and Scientific Research Publishing Inc. This work is licensed under the Creative Commons Attribution International License (CC BY 4.0).

http://creativecommons.org/licenses/by/4.0/

\section{(c) (i) Open Access}

\begin{abstract}
Radioactive contaminants, such as radium, radon, and uranium isotopes are naturally present in drinking water, and gas and oil extraction like hydraulic fracturing can exasperate radionuclide leakage into groundwater. The concentration of radionuclide in drinking water is dependent upon the water source and the underlying lithology within the aquifers. In United States, the Environmental Protection Agency regulates the level of radioactivity in drinking water via the gross alpha test, which is conducted to measure the emitted alpha particles as a result of the radioactive elements' natural decay. Radionuclides, such as radium and uranium, are known to cause bone cancer and other forms of cancer. Communities with crippling water purification infrastructure may be at a higher risk of being exposed to radionuclides, and this is a significant environmental justice concern. The radionuclide concentrations for the metropolitan or most populated city in each state in the United States and its territories (Puerto Rico, US Virgin Islands and Guam) were analyzed and correlated to the annual household income, to determine any disparities that maybe present. Lower income communities had elevated levels of radionuclides when compared to higher income communities which had lower frequency in elevated radionuclide contaminants.
\end{abstract}

\section{Keywords}

Radioactive Contaminants, Household Income, Income Per Capita, Environmental Justice, Water Quality, Radionuclides, Radium, Uranium, Radon, Cancer

\section{Introduction}

Radionuclides are intrinsically present in varying amounts in potable water. These radiological contaminants are released into the water source from rocks 
and bedrocks in the aquifers. The level of radionuclides is dependent upon the lithology of the underground structures (Agbalagba et al., 2012). Over time, erosion and dissolution increase the concentration of radiological elements that enter the water source (Ivanovich \& Harmon, 1992). Uranium-234 $\left({ }^{234} \mathrm{U}\right)$ and Uranium-238 $\left({ }^{238} \mathrm{U}\right)$ are the most abundant radionuclides in the Earth's crust and consequently in potable water. In addition, radium-226 $\left({ }^{226} \mathrm{Ra}\right)$, radium-228 $\left.{ }^{228} \mathrm{Ra}\right)$ and radon-222 $\left({ }^{222} \mathrm{Rn}\right)$ are environmental isotopes which are formed as result of radioactive decay of uranium and thorium present in rock and soil (Water Quality Association, 2020).

Radon and gross alpha radiation are released from the decay of various radioactive elements. Gross alpha can be present in drinking water because of the decay of uranium and thorium present in the Earth's crust (Ho et al., 2020). Although these radiations may not present any health risk outside the human body, ingesting them have been shown to be harmful, especially with long-term exposure (Ho et al., 2020).

Exposure to radiation can have various health risks depending on the source of radiation, the level of exposure (i.e. total dose), and the period of exposure (i.e. exposure length) (Ononugbo et al., 2013). The Environmental Protection Agency (EPA) enacted guidelines to mitigate the health risks associated with exposure to radionuclides, and consuming water near the federal drinking water standards (Table 1) puts consumers at low exposure levels. However, exposure of people to radionuclides through drinking water, when combined with other sources of exposure, can increase the likelihood of developing renal disease and cancer, such as radiation from medical treatments, living near coal mines and even traveling by airplanes (Avwiri et al., 2012). Considering the abundance of water and its necessity for everyday survival, the protection of water quality is an essential component of affective public health policy (WHO, 2017; IAEA, 2016).

To mitigate the health risks associated with exposure to radionuclides, the United States Environmental Protection Agency has regulated radium-226 $\left({ }^{226} \mathrm{Ra}\right)$ and radium-228 $\left({ }^{228} \mathrm{Ra}\right)$ to remain below 5 picocuries per litre of water (pCi/L), gross alpha including radium-226 to remain below $15 \mathrm{pCi} / \mathrm{L}$, and uranium to remain below $30 \mu \mathrm{g} / \mathrm{L}$, which has been converted by the EPA to be approximately $20 \mathrm{pCi} / \mathrm{L}$ (EPA, 2001).

Many of the drinking water standards were put in place decades ago and have not been updated. The Environmental Working Group (EWG) collaborates with state and federal agencies to obtain tap water quality data and provides health

Table 1. EPA maximum contaminant levels (MCLs) for radionuclides in drinking water (excluding radon).

\begin{tabular}{cc}
\hline Contaminant & MCL \\
\hline Combined radium-226 and radium-228 & $5 \mathrm{pCi} / \mathrm{L}$ \\
Gross alpha including Ra-226 & $15 \mathrm{pCi} / \mathrm{L}$ \\
Uranium & $30 \mu \mathrm{g} / \mathrm{L}$ or $20 \mathrm{pCi} / \mathrm{L}$ \\
\hline
\end{tabular}


guidelines, which may not be taken into consideration at a federal level. EWG regulations consider the heightened vulnerability of chemical toxicity to children, immunocompromised individuals, and pregnant women, to bridge the gap between the outdated federal standards (EWG, 2019; Environmental Protection Division, 2020). Hence, although many drinking water facilities are within legal compliance for toxic chemicals mandated by the federal agencies, these regulations are not always safe. These toxic chemicals and new emerging chemicals leave the general population susceptible to health problems. The Environmental Protection Agency sets the legal limits for combined radium (-226 \& -228) while the EWG health guidelines limit radium levels at $0.05 \mathrm{pCi} / \mathrm{L}$ (EWG, 2019). In addition to discrepancies between the health guidelines and federally mandated guidelines, social disparities are also an undeniable problem facing drinking water treatment facilities, as shown in a study correlating race/ethnicity and socioeconomic backgrounds to arsenic and nitrate levels (Balazs et al., 2011; Balazs et al., 2012). Previous studies have demonstrated water quality disparities correlating to socioeconomic background to demonstrate chemical, biological and physiccal contaminant levels (Karim et al., 2020), but this study is the first of its kind to elaborate on the correlation and association between radioactive contaminant levels in drinking water and socioeconomic background.

Radionuclides may be removed from drinking water source via reverse osmosis and ion exchange technology to increase drinking water quality (EPA, 2015). However, communities with crippling water purification infrastructure and lower income communities may be at a higher risk of being exposed to radionuclides, which is a significant environmental justice concern (Karim et al., 2020). To understand the social disparities, it is important to conduct a quantitative analysis in order to examine whether vulnerable populations, especially those with lower-average household incomes, are disproportionately impacted by radionuclides contaminants in drinking water. This research aims to analyze the possible disparities in drinking water quality in the metropolitan cities of each state in the United States and the US territories, including Puerto Rico, Guam, and the US Virgin Islands.

\section{Materials and Methods}

Secondary data related to the concentrations of radioactive contaminants was obtained from the annual water safety report for the metropolitan areas across the United States for 2019 and the details are provided in the following table (Table 2).

Additional information was collected by contacting water service offices to obtain information not readily available in the annual consumer confidence report (CCR). Data including median annual household income was obtained from the United States Census Bureau (United States Census Bureau, 2020). The water quality data was then prepared for descriptive statistical analysis. Histograms were used to illustrate the levels of total radionuclide in metropolitan 
Table 2. Radionuclide resource list for each state.

\begin{tabular}{|c|c|c|c|}
\hline State & Drinking Water & State & Drinking Water \\
\hline Alabama & $\begin{array}{c}\text { Alabama Water Quality } \\
\text { Report, } 2019\end{array}$ & Montana & $\begin{array}{c}\text { Montana Water } \\
\text { Quality Report, } 2019\end{array}$ \\
\hline Alaska & $\begin{array}{c}\text { Alaska Water Quality } \\
\text { Report, } 2019\end{array}$ & Nebraska & $\begin{array}{c}\text { Nebraska Water Quality } \\
\text { Report, } 2019\end{array}$ \\
\hline Arizona & $\begin{array}{c}\text { Arizona Water Quality } \\
\text { Report, } 2019\end{array}$ & Nevada & $\begin{array}{c}\text { Nevada Water Quality } \\
\text { Report, } 2019\end{array}$ \\
\hline Arkansas & $\begin{array}{c}\text { Arkansas Water Quality } \\
\text { Report, } 2019\end{array}$ & $\begin{array}{c}\text { New } \\
\text { Hampshire }\end{array}$ & $\begin{array}{c}\text { New Hampshire Water } \\
\text { Quality Report, } 2018\end{array}$ \\
\hline California & $\begin{array}{c}\text { California Water Quality } \\
\text { Report, } 2018\end{array}$ & New Jersey & $\begin{array}{c}\text { New Jersey Water } \\
\text { Quality Report, } 2019\end{array}$ \\
\hline Colorado & $\begin{array}{c}\text { Colorado Water Quality } \\
\text { Report, } 2019\end{array}$ & New Mexico & $\begin{array}{l}\text { New Mexico Water } \\
\text { Quality Report, } 2019\end{array}$ \\
\hline Connecticut & $\begin{array}{l}\text { Connecticut Water } \\
\text { Quality Report, } 2018\end{array}$ & New York & $\begin{array}{c}\text { New York Water } \\
\text { Quality Report, } 2018\end{array}$ \\
\hline Delaware & $\begin{array}{c}\text { Delaware Water Quality } \\
\text { Report, } 2019\end{array}$ & $\begin{array}{c}\text { North } \\
\text { Carolina }\end{array}$ & $\begin{array}{c}\text { North Carolina Water } \\
\text { Quality Report, } 2019\end{array}$ \\
\hline Florida & $\begin{array}{c}\text { Florida Water Quality } \\
\text { Report, } 2019\end{array}$ & $\begin{array}{l}\text { North } \\
\text { Dakota }\end{array}$ & $\begin{array}{l}\text { North Dakota Water } \\
\text { Quality Report, } 2019\end{array}$ \\
\hline Georgia & $\begin{array}{l}\text { Georgia Water Quality } \\
\text { Report, } 2019\end{array}$ & Ohio & $\begin{array}{c}\text { Ohio Water Quality } \\
\text { Report, } 2019\end{array}$ \\
\hline Hawaii & $\begin{array}{l}\text { Hawaii Water Quality } \\
\text { Report, } 2019\end{array}$ & Oklahoma & $\begin{array}{c}\text { Oklahoma Water } \\
\text { Quality Report, } 2019\end{array}$ \\
\hline Idaho & $\begin{array}{c}\text { Idaho Water Quality } \\
\text { Report, } 2019\end{array}$ & Oregon & $\begin{array}{c}\text { Oregon Water } \\
\text { Quality Report, } 2019\end{array}$ \\
\hline Illinois & $\begin{array}{l}\text { Illinois Water Quality } \\
\text { Report, } 2019\end{array}$ & Pennsylvania & $\begin{array}{l}\text { Pennsylvania Water } \\
\text { Quality Report, } 2019\end{array}$ \\
\hline Indiana & $\begin{array}{c}\text { Indiana Water Quality } \\
\text { Report, } 2019\end{array}$ & $\begin{array}{l}\text { Rhode } \\
\text { Island }\end{array}$ & $\begin{array}{l}\text { Rhode Island Water } \\
\text { Quality Report, } 2019\end{array}$ \\
\hline Iowa & $\begin{array}{c}\text { Iowa Water Quality } \\
\text { Report, } 2019\end{array}$ & $\begin{array}{l}\text { South } \\
\text { Carolina }\end{array}$ & $\begin{array}{c}\text { South Carolina Water } \\
\text { Quality Report, } 2019\end{array}$ \\
\hline Kansas & $\begin{array}{c}\text { Kansas Water Quality } \\
\text { Report, } 2019\end{array}$ & $\begin{array}{l}\text { South } \\
\text { Dakota }\end{array}$ & $\begin{array}{l}\text { South Dakota Water } \\
\text { Quality Report, } 2018\end{array}$ \\
\hline Kentucky & $\begin{array}{c}\text { Kentucky Water Quality } \\
\text { Report, } 2019\end{array}$ & Tennessee & $\begin{array}{c}\text { Tennessee Water } \\
\text { Quality Report, } 2019\end{array}$ \\
\hline Louisiana & $\begin{array}{c}\text { Louisiana Water Quality } \\
\text { Report, } 2019\end{array}$ & Texas & $\begin{array}{l}\text { Texas Water Quality } \\
\text { Report, } 2019\end{array}$ \\
\hline Maine & $\begin{array}{c}\text { Maine Water Quality } \\
\text { Report, } 2019\end{array}$ & Utah & $\begin{array}{l}\text { Utah Water Quality } \\
\text { Report, } 2019\end{array}$ \\
\hline Maryland & $\begin{array}{c}\text { Maryland Water Quality } \\
\text { Report, } 2019\end{array}$ & Vermont & $\begin{array}{c}\text { Vermont Water } \\
\text { Quality Report, } 2019\end{array}$ \\
\hline Massachusetts & $\begin{array}{l}\text { Massachusetts Water } \\
\text { Quality Report, } 2019\end{array}$ & Virginia & $\begin{array}{c}\text { Virginia Water } \\
\text { Quality Report, } 2019\end{array}$ \\
\hline Michigan & $\begin{array}{c}\text { Michigan Water Quality } \\
\text { Report, } 2018\end{array}$ & Washington & $\begin{array}{l}\text { Washington Water } \\
\text { Quality Report, } 2019\end{array}$ \\
\hline
\end{tabular}




\begin{tabular}{cccc} 
Continued & & \\
\hline Minnesota & $\begin{array}{c}\text { Minnesota Water Quality } \\
\text { Report, 2018 }\end{array}$ & $\begin{array}{c}\text { West } \\
\text { Virginia }\end{array}$ & $\begin{array}{c}\text { West Virginia Water } \\
\text { Quality Report, 2019 }\end{array}$ \\
Mississippi & $\begin{array}{c}\text { Mississippi Water Quality } \\
\text { Report, 2018 }\end{array}$ & Wisconsin & $\begin{array}{c}\text { Wisconsin Water } \\
\text { Quality Report, 2018 }\end{array}$ \\
Missouri & Missouri Water Quality & Wyoming & Wyoming Water \\
& Report, 2019 & & Quality Report, 2019 \\
Guam & Guam Water Quality & Puerto Rico & Puerto Rico Water \\
& Report, 2019 & & \\
US Virgin Islands & Zack et al., 2020 & & \\
\hline
\end{tabular}

areas across the United States, Puerto Rico, US Virgin Islands and Guam for 2019. Tables were generated to record income per capita for the metropolitan city of each state and US territories (provided by the Census Bureau) and their drinking water source (provided by the state and local water services departments), and correlated to the levels of total radionuclide concentrations. The disparities among the average household income in different counties and their water quality are shown using multi-variable charts.

\section{Results and Discussion}

The correlation between the average household income radionuclide levels is examined to determine the impact of median household income on the quality of drinking water. The drinking water sources in each state are different; however, most of the water sources are either from surface water or groundwater, as shown in Table 3. Raw water chemistry and composition can be influenced by many factors including human activity and wildlife population surrounding the water source, but rock formation is particularly responsible for level of radionuclides present in drinking water due to the decay of uranium from Earth's crust. Radium, radon, and uranium isotopes are an intrinsic part of water, but these radionuclide levels are exasperated due gas and oil extraction like hydraulic fracturing which can leak into groundwater (USGS, 2020). Hence, the concentration of radionuclide in drinking water is dependent upon the water source (Table 3 ) and the underlying lithology within the aquifers.

In the United States, the Environmental Protection Agency regulates the level of radioactivity in drinking water via the gross alpha test, which is conducted to measure the emitted alpha particles due to the radioactive elements' natural decay. The details and regulatory limits are indicated in Table 1, and were put into place decades ago. Research has shown that health agencies recommend radionuclides in drinking water to be significantly lower than the federal mandates.

The radionuclide concentrations for the metropolitan or most populated city in each state in the United States, Puerto Rico, Guam, and US Virgin Islands were analyzed and correlated to the annual household income (Table 4) to determine disparities that maybe present, as shown in Figure 1. 
Table 3. Drinking water source in the metropolitan city of each state in the United States.

\begin{tabular}{|c|c|c|c|}
\hline State & Drinking Water Source & State & Drinking Water Source \\
\hline Alabama & Potomac River & Montana & Missouri River \\
\hline Alaska & Eklutna Lake & Nebraska & Platte River \\
\hline Arizona & Salt and Verde Rivers & Nevada & $\begin{array}{l}\text { Kings Creek, Ash } \\
\text { Creek and Marlette }\end{array}$ \\
\hline Arkansas & Lake Winona and lake Maumelle & New Hampshire & Bellamy Reservoir \\
\hline California & Sacramento and American River & New Jersey & Pequannock Watershed \\
\hline Colorado & Strontia Springs & New Mexico & $\begin{array}{l}\text { Bernalillo Rivers } \\
\text { and Creeks }\end{array}$ \\
\hline Connecticut & Farmington River & New York & $\begin{array}{l}\text { Catskill/Delaware } \\
\text { and Croton }\end{array}$ \\
\hline Delaware & Heron Bay & North Carolina & Falls Lake Reservoir \\
\hline Florida & Floridan Aquifer & North Dakota & Red River \\
\hline Georgia & Chattahoochee River & Ohio & Scioto River \\
\hline Hawaii & Haiku Tunnel and Well & Oklahoma & $\begin{array}{l}\text { Canton Lake and } \\
\text { McGee Creek }\end{array}$ \\
\hline Idaho & Boise River & Oregon & Clear Creek \\
\hline Illinois & Lake Springfield & Pennsylvania & Schuylkill River \\
\hline Indiana & White River & Rhode Island & Scituate Reservoir \\
\hline Iowa & Raccoon and Des Moines River & South Carolina & Lake Keowee \\
\hline Kansas & Kansas River & South Dakota & $\begin{array}{l}\text { Hilger's and Whiskey } \\
\text { Gulch basin }\end{array}$ \\
\hline Kentucky & Old Hickory Lake & Tennessee & Cumberland River \\
\hline Louisiana & Southern Hills Aquifer & Texas & Lake Austin \\
\hline Maine & China Lake & Utah & Cottonwood Creek \\
\hline Maryland & $\begin{array}{l}\text { Magothy River, Upper } \\
\text { and Lower Patapsco }\end{array}$ & Vermont & Berlin Pond \\
\hline Massachusetts & Ware River & Virginia & James River \\
\hline Michigan & Saginaw Sandstone Aquifer & Washington & Cedar River \\
\hline Minnesota & Mississippi River & West Virginia & Elk River \\
\hline Mississippi & Pearl River & Wisconsin & Lake Michigan \\
\hline Missouri & Missouri River & Wyoming & $\begin{array}{l}\text { Granite Springs } \\
\text { Reservoir }\end{array}$ \\
\hline Guam & Northern Guam Lens Aquifer & Puerto Rico & Karst Aquifer \\
\hline US Virgin Islands & Seawater & & \\
\hline
\end{tabular}

To investigate disparities in drinking water quality, total radionuclides were examined, including combined radium $(5 \mathrm{pCi} / \mathrm{L})$, uranium $(20 \mathrm{pCi} / \mathrm{L})$ and gross alpha $(15 \mathrm{pCi} / \mathrm{L})$ for a total of $40 \mathrm{pCi} / \mathrm{L}$. Many states failed to document uranium and gross alpha levels. However, most of the states and the US territories 
Table 4. Median household income along with income per capita (US dollars) for metropolitan city of each state in the United States, Puerto Rico, Guam, and US Virgin Islands. The incomes are separated by a slash (/).

\begin{tabular}{|c|c|c|c|}
\hline State & $\begin{array}{l}\text { Median household } \\
\text { income/income per } \\
\text { capita (\$) }\end{array}$ & State & $\begin{array}{c}\text { Median household } \\
\text { income/income per } \\
\text { capita (\$) }\end{array}$ \\
\hline Alabama & $38,902 / 24,780$ & Montana & $57,172 / 33,107$ \\
\hline Alaska & $83,648 / 30,129$ & Nebraska & $59,266 / 21,265$ \\
\hline Arizona & $57,957 / 21,907$ & Nevada & $53,575 / 26,011$ \\
\hline Arkansas & $53,173 / 34,546$ & New Hampshire & $73,022 / 29,296$ \\
\hline California & $62,474 / 29,906$ & New Jersey & $72,561 / 19,313$ \\
\hline Colorado & $68,377 / 32,399$ & New Mexico & $51,643 / 24,745$ \\
\hline Connecticut & $73,151 / 34,310$ & New York & $67,274 / 35,811$ \\
\hline Delaware & $69,479 / 29,007$ & North Carolina & $60,764 / 24,698$ \\
\hline Florida & $41,818 / 25,601$ & North Dakota & $53,309 / 26,059$ \\
\hline Georgia & $65,345 / 25,288$ & Ohio & $52,971 / 23,020$ \\
\hline Guam & $61,937 / 16,549$ & Oklahoma & $53,973 / 25,074$ \\
\hline Hawaii & $80,212 / 36,339$ & Oregon & $73,097 / 31,377$ \\
\hline Idaho & $63,179 / 25,723$ & Pennsylvania & $46,116 / 22,874$ \\
\hline Illinois & $57,238 / 23,074$ & Puerto Rico & $20,296 / 12,081$ \\
\hline Indiana & $47,678 / 23,198$ & Rhode Island & $42,158 / 25,435$ \\
\hline Iowa & $47,275 / 23,316$ & South Carolina & $63,459 / 28,649$ \\
\hline Kansas & $46,890 / 23,326$ & South Dakota & $50,017 / 26,959$ \\
\hline Kentucky & $57,405 / 21,756$ & Tennessee & $55,873 / 23,994$ \\
\hline Louisiana & $57,843 / 27,934$ & Texas & $52,210 / 24,516$ \\
\hline Maine & $56,977 / 24,132$ & Utah & $73,730 / 24,277$ \\
\hline Maryland & $85,203 / 29,771$ & Vermont & $50,324 / 31,095$ \\
\hline Massachusetts & $71,834 / 37,311$ & Virginia & $111,574 / 33,671$ \\
\hline Michigan & $31,283 / 21,701$ & Washington & $70,598 / 39,322$ \\
\hline Minnesota & $63,590 / 35,388$ & West Virginia & $41,701 / 27,138$ \\
\hline Mississippi & $55,700 / 26,655$ & Wisconsin & $70,463 / 25,163$ \\
\hline Missouri & $43,889 / 22,698$ & Wyoming & $63,235 / 29,980$ \\
\hline US Virgin Islands & $37,254 / 21,362$ & & \\
\hline
\end{tabular}

reported the combined radium levels. US Virgin Islands did not report any radionuclide levels. The data obtained for Puerto Rico was from a report conducted in 2017 showing that Puerto Rico had five violations for elevated radionuclide levels (NRDC, 2017). However, considering that radionuclides do not decay from the environment as quickly, these results are still valid, indicating that Puerto Rican drinking water does not meet federal regulations. As shown in Figure 1, as the income increases, radionuclides contaminants become less 


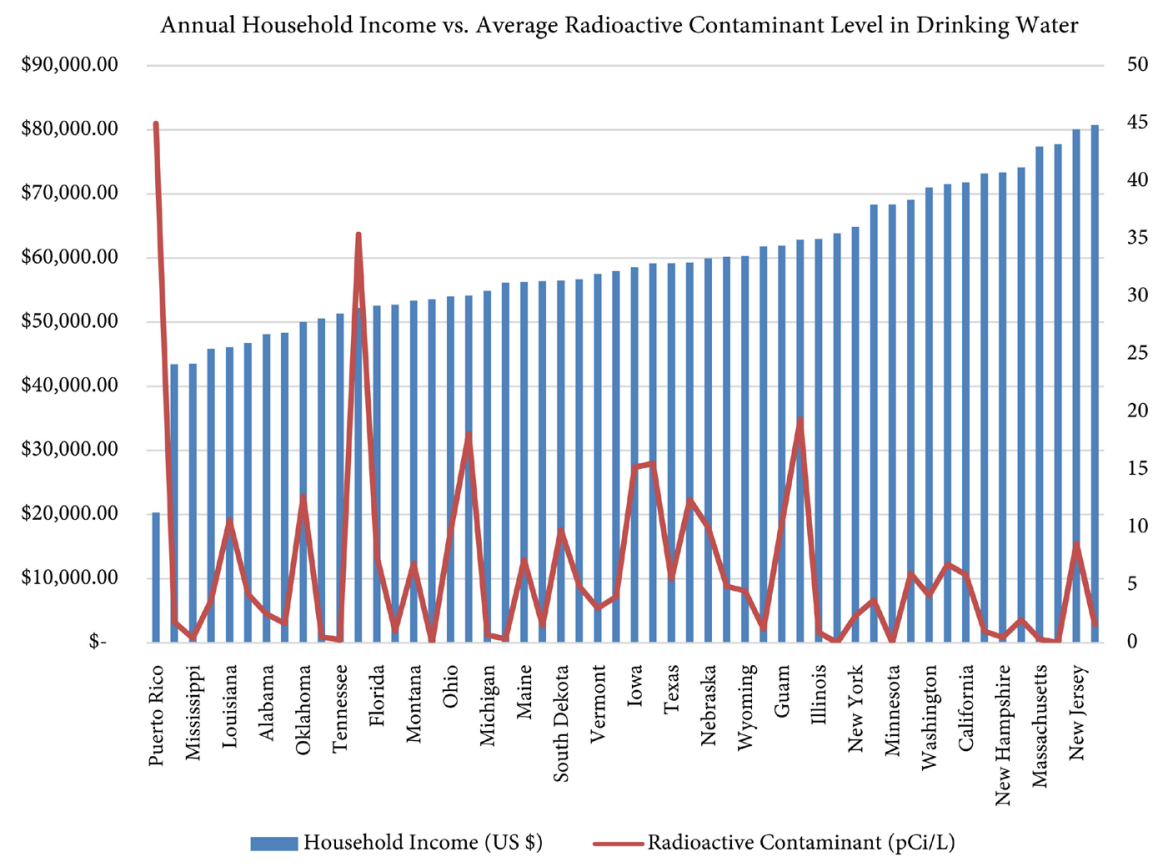

Figure 1. Average radiological contaminant present in drinking water as it correlates to income per capita in the metropolitan city of each state. Data for Missouri, Hawaii, and Minnesota was not readily available, as these states do not report on radionuclides. Data for Puerto Rico was obtained from a previous study conducted in 2017, where there were five violations for radionuclides in drinking water (NRDC, 2017).

frequent in drinking water. Indiana, Idaho, Iowa, Delaware and Pennsylvania had the highest levels of radionuclides. These state's incomes fall in the lowerand middle-class brackets. However, states with higher incomes did not have high levels of radionuclides in their drinking water.

Upon closer examination, Idaho's combined radium, uranium and gross alpha levels were $2.3,18$, and $6.1 \mathrm{pCi} / \mathrm{L}$ respectively, for a total of $35.4 \mathrm{pCi} / \mathrm{L}$ out of 40 $\mathrm{pCi} / \mathrm{L}$ as mandated by the EPA. Indiana's combined radium, uranium and gross alpha levels were $1.73,9.7$, and $6.7 \mathrm{pCi} / \mathrm{L}$, respectively. Iowa's combined radium, uranium and gross alpha levels were 2.2, 1.9, and $11.1 \mathrm{pCi} / \mathrm{L}$, respectively. Pennsylvania's combined radium, and gross alpha levels were 3.95 and 11.6, respectively. Finally, Delaware's uranium and gross alpha levels were 12.78 and 6.6 pCi/L, respectively. Furthermore, Guam also had moderately elevated levels of radionuclides. Data for Missouri, Hawaii and Minnesota was not readily available, as these states did not report the levels of radionuclides. The general trend within the graph in Figure 1 indicates elevated radionuclide levels among lowand middle-income brackets, but significantly lower radionuclide among higher income states.

Although there were violations in Puerto Rico, the US states remained well below the federally mandated regulations for radionuclides in drinking water. However, these regulations were set two decades ago, and according to the Environmental Working Group (EWG), are not low enough to mitigate health issues that might arise due to exposure to radionuclides. According to the EWG 
health guidelines, radium levels should remain $0.05 \mathrm{pCi} / \mathrm{L}$ compared to the 5 $\mathrm{pCi} / \mathrm{L}$, which is 100 times more than the health guideline recommendations. In addition, the EPA standard for uranium is at about $20 \mathrm{pCi} / \mathrm{L}$ which is 46.5 times higher than the EWG health guidelines of $0.43 \mathrm{pCi} / \mathrm{L}$. Tennessee ranks among the lowest for combined radium at $0.26 \mathrm{pCi} / \mathrm{L}$, which is 5.2 times the EWG health guideline limits and significantly lower than the national average of 0.47 pCi/L (EWG, 2019).

Finally, the general trend in Figure 1 shows that low- and middle-income communities had higher radionuclides in drinking water compared to high income communities. Although, there was one incident where Delaware had a slightly more elevated radioactive contaminant level within the high-income bracket group, perhaps this is due to an outlier in the compiled data. However, the general scheme and pattern indicate that there is much more frequency in the elevated radionuclide contmiant levels among low- and middle-income bracket groups. These disparities in radionuclide levels in correlation to income levels are in conjunction with water justice inequalities that have been previously investigated by scientists and environmentalists. Our findings that lower income communities face injustice obtaining and sustaining high water quality agree with previous investigations (Karim et al., 2020). In addition, federally mandated regulations should be reviewed to better mitigate health problems that could arise from drinking contaminated water.

\section{Conclusion}

Water resource management is a global concern and protecting the quality of drinking water is a public health duty. Due to the carcinogenic effects of radionuclides, the presence of these contaminants in drinking water at a disproportionate level in lower income communities is dire and of social and epidemiological interest. As shown in this study, in 2019, Indiana, Idaho, Iowa, Delaware and Pennsylvania with median household incomes in the low- to mid-income communities demonstrated high levels of radionuclides. In contrast, communities with high incomes had significantly lower levels of radionuclides in their drinking water. In addition, Puerto Rico, a US territory where water quality must meet US EPA standards has five violations for elevated levels of radionuclides in drinking water. In addition, Guam's drinking water was also slightly higher than many US states. Finally, although all the US states met the EPA's legal standards, which were put in place two decades ago and are highly outdated. According to the EWG's health guidelines, the standards for radionuclides are significantly lower than federal mandates.

Man-made and naturally occurring factors play a significant role in the quality and composition of water. However, public water quality should not be influenced by socioeconomic factors. Based on the results from data obtained across the United States, poor water quality is much more frequent in less affluent communities, due to the presence of industrial activity, human activity, and is exasperated by an already collapsing water infrastructure. 
Based on this study, it is recommended for water infrastructures to be improved by incorporating newer technology to reduce radionuclides from drinking water, as they pose health risks. In addition, federal regulations must be improved and restrictions adequately imposed for radioactive material. Finally, states that do not report on radionuclides must be held accountable for not making this information readily available and accessible to consumers. Information obtained from the present study could also be used to draft improved health guidelines, and for the purpose of resource allocation to ensure that the general population is better informed about drinking water quality within their communities.

\section{Acknowledgements}

We acknowledge the financial support from the USDA National Institute of Food and Agriculture, Grant\# TENX-1608-FS. We thank US Department of Education, Title III Part B, grant number P031B090214 for partial financial support.

\section{Conflicts of Interest}

The authors declare no conflicts of interest regarding the publication of this paper.

\section{References}

Agbalagba, E. O., Avwiri, G. O., \& Ononugbo, C. P. (2012). Activity Concentration and Radiological Impact Assessment of ${ }^{226} \mathrm{Ra},{ }^{228} \mathrm{Ra}$ and ${ }^{40} \mathrm{~K}$ in Drinking Waters from (OML) 30, 58 and 61 Oil Fields and Host Communities in Niger Delta Region of Nigeria. Journal of Environmental Radioactivity, 116, 197-200.

https://doi.org/10.1016/j.jenvrad.2012.08.017

Alabama, Annual Water Quality Report (2019). https://www.mwwssb.com/en/Community/Water\%20Quality\%20Reports

Alaska, Water Quality Report (2019).

https://www.awwu.biz/home/showdocument?id=1803

Arizona, Water Quality Report (2019). https://www.phoenix.gov/waterservicessite/Documents/wsdprimarywqr.pdf

Arkansas, Water Quality Report (2019). http://www.carkw.com/wp-content/uploads/2020/06/CARW-023-General-WQR_Final .pdf

Avwiri, G. O., Osimobi, J. O., \& Agbalagba, E. O. (2012). Evaluation of Radiation Hazard Indices and Excess Lifetime Cancer Risk Due to Natural Radioactivity in Soil Profile of Udi and Ezeagu Local Government Areas of Enugu State, Nigeria. Journal of Environmental and Earth Sciences, 1, 1-10.

Balazs, C. L., Morello-Frosch, R., Hubbard, A. E., \& Ray, I. (2012). Environmental Justice Implications of Arsenic Contamination in California's San Joaquin Valley: A Cross-Sectional, Cluster-Design Examining Exposure and Compliance in Community Drinking Water Systems. Environmental Health, 11, Article No. 84. https://doi.org/10.1186/1476-069X-11-84

Balazs, C., Morello-Frosch, R., Hubbard, A., \& Ray, I. (2011). Social Disparities in Ni- 
trate-Contaminated Drinking Water in California's San Joaquin Valley. Environmental Health Perspectives, 119, 1272-1278. https://doi.org/10.1289/ehp.1002878

California, Consumer Confidence Report (2018). https://www.mariposacounty.org/DocumentCenter/View/78984/Public-Works-2018-C onsumer-Confidence-Report?bidId=

Colorado, Water Quality Report (2019). https://www.denverwater.org/sites/default/files/water-quality-report-2019.pdf

Connecticut, Water Quality Report (2018). https://www.rwater.com/media/3497/2018-consumers-annual-report-on-water-quality =web.pdf

Delaware, Water Quality Report (2019). https://www.dovertownship.org/wp-content/uploads/2020/05/2019-CCR.pdf

Environmental Protection Division (2020). https://epd.georgia.gov/radium-and-uranium-public-drinking-water-systems

EPA (2001). Radionuclide Rule: A Quick Reference Guide. https://nepis.epa.gov/Exe/ZyPDF.cgi?Dockey=30006644.txt

EPA (2015). Radionuclides in Drinking Water. https://cfpub.epa.gov/safewater/radionuclides/radionuclides.cfm?action=Rad_Reverse \%20Osmosis

EWG (2019). Environmental Working Group's Tap Water Database. https://www.ewg.org/tapwater/system.php?pws=TN0000494

Florida, Water Quality Report (2019). https://www.fortlauderdale.gov/departments/public-works/water-quality-report-online -registration-form

Georgia, Water Quality Report (2019). https://drive.google.com/file/d/10NYyDp0EZCpFthZjaNDgDmXF9d_fEYTm/view

Guam, Water Quality Report (2019). http://guamwaterworks.org/wp-content/uploads/2019/07/2018-Water-Quality-Report. pdf

Hawaii, Water Quality Report (2019). http://www.kauaiwater.org/wqr_anahola.pdf

Ho, P., Hung, L., Minh, V., Chinh, D., Thanh, T., \& Tao, C. (2020). Simultaneous Determination of Gross Alpha/Beta Activities in Groundwater for Ingestion Effective Dose and Its Associated Public Health Risk Prevention. Scientific Reports, 10, Article No. 4299. https://doi.org/10.1038/s41598-020-61203-y

IAEA (2016) Criteria for Radionuclide Activity Concentrations for Food and Drinking Water (pp. 10-25).

Idaho, Water Quality Report (2019). https://www.mysuezwater.com/sites/default/files/IDCCR2018.pdf

Illinois, Annual Water Quality Reports (2019). https://www.lakecountyil.gov/359/Water-Quality-Reports

Indiana, Water Quality Report (2019). https://www.citizensenergygroup.com/My-Home/Utility-Services/Water/Water-Qualit y/2019-Drinking-Water-Report.pdf

Iowa, Water Quality Report (2019). http://www.dmww.com/upl/documents/water-quality/lab-reports/water-quality-report s/consumer-confidence-report-19.pdf

Ivanovich, M., \& Harmon, R. S. (1992) Uranium-Series Disequilibrium (2nd ed.). Oxford: 
Clarendon Press.

Kansas, Water Quality Report (2019). https://www.goddardks.gov/ArchiveCenter/ViewFile/Item/287

Karim, K., Guha, S., \& Beni, R. (2020). Comparative Analysis of Water Quality Disparities in the United States in Relation to Heavy Metals and Biological Contaminants. Water, 12, 967. https://doi.org/10.3390/w12040967

Kentucky, Annual Water Quality Report (2019). http://www.amwater.com/ccr/Owenton.pdf

Louisiana, Water Quality Report (2019). http://www.brwater.com/brwc_ccr.pdf

Maine, Consumer Confidence Report (2019). http://yarmouthwaterdistrict.org/wp-content/uploads/2019/04/2018-Consumer-Confid ence-Report.pdf

Maryland, Water Quality Report (2019). https://publicworks.baltimorecity.gov/sites/default/files/2019\%20Baltimore\%20City\%2 0Water\%20Quality\%20Report.pdf

Massachusetts, Water Quality Report (2019). https://www.ewg.org/tapwater/system.php?pws=MA4020004

Michigan, Water Quality Report (2018). https://detroitmi.gov/sites/detroitmi.localhost/files/2019-06/DWSD\%20Water\%20Qual ity\%20Report\%20for\%202018\%20\%28Published\%20June\%202019\%29.pdf

Minnesota, Water Quality Report (2018). http://www2.minneapolismn.gov/www/groups/public/@publicworks/documents/webc ontent/wcmsp-218885.pdf

Mississippi, Water Quality Report (2018). https://msdh.ms.gov/ccr/2018/ccrList.html

Missouri, Water Quality Report (2019). http://www.stlwater.com/ccr.pdf

Montana, Water Quality Report (2019). https://www.nps.gov/yell/learn/nature/waterquality-mammoth.htm

Nebraska, Water Quality Report (2019). https://www.lincoln.ne.gov/city/ltu/water/pdf/water-quality-report.pdf

Nevada, Water Quality 2018 Report (2019). https://www.lvvwd.com/water-quality/reports/index.html

New Hampshire, Annual Water Quality Report (2018). https://www.manchesternh.gov/Portals/2/Departments/water_works/watersupply/CCR _Web_Version_2018.pdf

New Jersey, Water Quality Report (2019). http://rentonil.org/wp-content/uploads/2019/04/2018wqreport.pdf

New Mexico, Water Quality Report (2019). https://www.newmexicowater.com/docs/ccr/2019/cg-2019.pdf

New York, Water Quality Report (2018). https://www1.nyc.gov/assets/dep/downloads/pdf/water/drinking-water/drinking-water -supply-quality-report/2018-drinking-water-supply-quality-report.pdf

North Carolina, Water Quality Report (2019).

https://cityofraleigh0drupal.blob.core.usgovcloudapi.net/drupal-prod/COR25/2019CC R.pdf

North Dakota, Water Quality Report (2019).

https://bismarcknd.gov/DocumentCenter/View/35538/2019-Bismarck-Water-Quality$\underline{\text { Report }}$ 
NRDC (2017).

https://www.nrdc.org/sites/default/files/threats-on-tap-drinking-water-puerto-rico-ip. pdf

Ohio, Water Quality Report (2019).

https://www.columbusutilities.org/wp-content/uploads/ccu-2019-water-quality-reportWEB.pdf\#: :text

Oklahoma, Drinking Water Quality Report (2019). https://www.okc.gov/home/showdocument?id=14292

Ononugbo, C. P., Avwiri, G. O., \& Egieya, J. M. (2013). Evaluation of Natural Radionuclide Content in Surface and Ground Water and Excess Lifetime Cancer Risk Due to Gamma Radioactivity. Academic Research International, 4, 636-647.

Oregon, Drinking Water Quality Report (2019).

https://www.portlandoregon.gov/water/article/244813

Pennsylvania, Drinking Water Quality Report (2019). http://www.eriewater.org/wqr/2019wqr.erie.pdf

Puerto Rico, Water Quality Report (2019). https://www.nrdc.org/sites/default/files/threats-on-tap-drinking-water-puerto-rico-ip. pdf

Rhode Island, Water Quality Report (2019).

https://www.provwater.com/water_quality/annual_reports/2019

South Carolina, Water Quality Report (2019). https://issuu.com/columbiascwater/docs/2019_water_quality_report?e=35422108/7853 $\underline{8296}$

South Dakota, Drinking Water Report (2018). https://cantonsd.org/wp-content/uploads/2019/03/2018-drinking-water-report.pdf

Tennessee, Water Quality Report (2019). https://www.nashville.gov/Portals/0/SiteContent/WaterServices/docs/reports/CCR2019 .pdf

Texas, Water Quality Report (2019). http://dallascityhall.com/departments/waterutilities/DCH\%20Documents/pdf/water-q uality-report.pdf

USGS (2020). Radionuclides. https://www.usgs.gov/mission-areas/water-resources/science/radionuclides?qt-science center_objects $=0 \#$ qt-science_center_objects

United States Census Bureau (2020). https://www.census.gov/topics/population.html

Utah, Water Quality Report (2019). http://www.slcdocs.com/utilities/CCR.pdf

Vermont, Annual Water Quality Report (2019). https://www.rutlandcity.org/vertical/Sites/\%7B7B135F7F-3358-43FC-B154-A313EF1F3 222\%7D/uploads/CCR2019(1).pdf

Virginia, Water Quality Report (2019). https://www.fairfaxwater.org/sites/default/files/newsletters/ccr_2019.pdf

Washington, Water Quality Report (2019). https://www.cityofportorchard.us/documents/city-of-port-orchard-water-quality-repor t/

Water Quality Association (2020). Radium in Drinking Water. https://www.wqa.org/Learn-About-Water/Common-Contaminants/Radium

West Virginia, American Water (2019). http://www.amwater.com/ccr/kanawhavalley.pdf 
WHO (2017). Guidelines for Drinking-Water Quality (4th ed., Chap. 9, pp. 203-218). Geneva: WHO Publications.

Wisconsin, Water Quality Report (2018).

https://city.milwaukee.gov/ImageLibrary/Groups/WaterWorks/files/Annual-Reports/2 018-CCR-docs/2018DistributionSystemWaterQuality.pdf

Wyoming, Water Quality Report (2019).

https://www.cheyennebopu.org/Your-Water/Water-Quality/CCR

Zack, A., Rodriques-Alonso, T., \& Roman-Mas, A. (2020). U.S. Virgin Islands Ground-Water Quality. https://pubs.usgs.gov/of/1987/0756/report.pdf

https://doi.org/10.3133/ofr87756 